Research.

\title{
ANALYSIS OF WORKING CAPITAL TURNOVER IMPACT TOWARD PROFITABILITY AND ACCOUNTING IMPLICATION AT PT. MULTI STRADA ARAH SARANA Tbk.
}

\author{
Muhammad Nur Rizqi \\ Lecturer at STIE Binaniaga, Bogor
}

\begin{abstract}
This research is meant to examine the working capital cash flow which are consist of three sub variables: cash flow $\left(X_{1}\right)$, receivable turnover $\left(X_{2}\right)$, and inventory turnover $\left(X_{3}\right)$ as the independent variables to profitability as $(Y)$ variable. The data is taken from financial statements in form of balance sheet and income statements that have been audited at one of the national tires company, PT. Multi Strada Arah Sarana. Tbk in the past 7 years for 2010-2016 periods. Multiple linear regressions, coefficient determination, coefficient correlation and T-test are used to analyze the impact of working capital turnover, receivable turnover, and inventory turnover toward profitability in the company. In the other hand, descriptive analysis is used to analyze the accounting implication. The result of this research shows that there is $38.6 \%$, a small impact between cash flow, account receivable turnover and inventory turnover on the coefficient determination test, but the others are 61,4\%. The T-test shows that cash flow, account receivable turnover and inventory turnover has no significant impact toward ROI. This result is strengthen by F-test (Anova) which says that there is no impact between the independent variables (cash flow, receivable turnover, and inventory turnover) at the same time toward profitability (ROI).

Accounting implication meant in this study is the basic impact from account receivable and inventory as current assets that shows the company sells more on credit sales. In the other hand, the inventory turnover shows that the sales really often happen. In this case, the company should pay attention to the cash flow because it will give some information about the use and the function of net cash.
\end{abstract}

Keywords: capital working, ROI, and operating activity.

\section{INTRODUCTION}

National tires industry has a large market, continuing expansion has made the customers recognize and accept the products. By using the expansion, the company needs more capitals. Capital is the elements that being used as capital expenditure and revenue expenditure. The use of capital by the management will cause some changes in the Map business of the company. The management must look at the future by looking $t$ the business projection and also the progressive profitability. Profitability in a company can be measured in quarter, semester even annual which hopefully increase. The high profitability will give some impacts toward the operational activity and policies in the management. Therefore, the optimal working capital like cash turnover, receivable turnover and inventory turnover. By looking at those three aspects, a company can measure the income statements. The working capital has become a fundamental factor which can give a big impact toward the ability of a company to gain some profit, therefore a research needs to be conducted at a national tire industry to examine whether the industry experience the theory or not. In the other hand, it is a must in accounting to see the impact of the movements of working capital, especially on the operational activity on the company's cash flow. 
A. Problems identification

1. Does the cash flow give any impact toward profitability (ROI)?

2. Does the receivable turnover give any impact toward profitability $(\mathrm{ROI})$ ?

3. Does the inventory turnover give any impact toward profitability (ROI)?

4. Do the three sub working capital turnover at the same time give any impact toward profitability (ROI)?

5. How does the accounting implication from cash flow, receivable turnover and inventory turnover connect to operation activity?

B. Aims

1. To analyze the impact of cash flow towards profitability (ROI).

2. To analyze the impact of receivable turnover towards profitability (ROI).

3. To analyze the impact of inventory turnover towards profitability (ROI).

4. To determine the impact of all sub working capital turnover at the same time towards profitability (ROI).

5. To determine the accounting implication of the research.

\section{LITERATURE REVIEW}

Working capital divided into three elements, those are cash, account receivable and inventory. The three elements are the most liquid things in the financial statement. Because of their liquidity level, every company must have those three elements. The company itself tries to make the working capital turns. The more often turnover happens, the better the company's condition. That condition shows company's ability to get the income.

A. Cash is the payment tools that ready to be used as an investment or as tools to do the operational activity whenever the company needs. Therefore, cash covers all company's payments tools that is saved in the company or bank and ready to be used (Rudianto, 2009).

Three motif in having cash are:

1. Transaction motif. It means that the company provide cash to pay any kinds of business transactions, regularly or irregularly.

2. Stand by motif. It means that the company keep the cash balance in order to fulfill unpredictable outcome.

3. Speculation motif. It means that the company wants to gain profit by having or inventing the cash in form of liquid investment. (Maynard, Keynes 2006).

B. Statement of Cash Flow

Statement of cash flow describe the changing of cash in certain period. The aim of this statement is to provide relevant information about the income and outcome of the cash in a period.

Management needs statement of cash flow because:

1. Net income cannot give an accurate picture of company's performance in certain period.

2. Cash flow statement consists of information about operating activity, investment and financing. All things that need to be known and overviewed in a statement.

3. As a forecast by analyzing if the operating plans, investment, and financing can be done.

As mentioned above, both cash in-flows and out-flows divided into three main categories, those are:

Muhammad Nur Rizqi: Analysis of Working Capital Turnover Impact Toward Profitability and Accounting Implication at PT. Multi Strada Arah Sarana Tbk. 
1. Operating Activity

Is transactions and things which will determine net income like cash income from sales of goods or services as a cash flow for the business. The other income cash come from interest, dividend, etc. Disbursement cash flow in this activity is the payment for inventory purchase, payroll, tax, interest, rent, etc.

2. Investing Activity

The main activity is purchase and sales of fixed assets such as land, building, tools, etc. The company buys those things not to resell it. The activity in the category includes purchase and sales financial instrument which aim not to trade them.

3. Financing Activity

Is transaction that happen when cash obtained and paid back to the stockholders or creditors. For example, cash that produced from issuance of share and bond, moreover, there are also share payment which are recovered or paid off bond and dividend payment.

\section{Cash Turnover, Receivable Turnover, and Inventory Turnover}

The discussion of cash flow pattern, both positive and negative, cannot be separated from how many times the cash turnover in a period, and there must be any credit transaction that gives impact toward the amount of the cash. The information about the impactiveness of inventory supply as $n$ operating activity is important to show the net income in a company.

1. Cash Turnover is an activity that shows the cash ability to earn income, so the company know how many times cash turnover in a period. The formula to get the cash turnover is:

$$
\text { Cash Turnover Ratio }=\frac{\text { Net Revenue }}{\text { Average Cash Balance }}
$$

The higher, the better the cash turnover ratio because it shows the efficiency of the use of the cash. But, if the cash turnover ratio is too high, it shows that the cash available is too small to do the sales operating.

2. Receivable Turnover. Some types of accounts receivables are: account receivable, notes receivable and other receivable. Receivable turnover is the number of time per year that a business collects its average account receivable depends on the payment requirements. The longer the payment requirements, the longer capital stick to the receivable. It means that the number of turnover in a period becomes lower. (Riyanto, 2008).

$$
\text { Receivable Turnover Ratio }=\frac{\text { Net Annual Credit Sales }}{\text { Average Account Receivable }}
$$

3. Inventory Turnover. The term of inventory turnover is used to show he number of goods that company has to be resold or used to produce other goods. (Baridwan, 2008). Inventory turnover in a company can be categorized based on the types and position of the goods on process.

The types of inventory are:

1) Direct Material Inventory

2) Work in Process Inventory

3) Finished Goods

To measure inventory efficiency, we need to know the number of inventory turnover ratio by comparing the cost of goods sold and average inventory. Inventory turnover formula is 


$$
\text { Inventory Turnover Ratio }=\quad \frac{\text { Cost of Goods Sold }}{\text { Average Inventory }}
$$

Inventory turnover ratio shows the number of fund in the inventory turnover in a period. The higher the number of turnover the less working capital that needs to be invested. The higher the number of inventory turnover the smallest the risk of loos by the decreasing cost or sconsumers' taste.

\section{Profitability}

Profitability is company's ability to gain profit or income that relates to sales, total assets, or capitals (Raharjaputra, 2009). To measure company's ability to gain profit, we use profitability. The ratio is used to measure company's ability to earn profitability in sales, assets, and capital stocks.

\section{Hanafi and Abdul Halim said there are three kinds of ratio:}

1. Profit Margin. This ratio measures company's ability to gain net income on certain sales level.

2. Return On Asset. This ratio measures company's ability to gain net income on certain asset level.

3. Return On Equity. This ratio measures company's ability to gain profit on certain capital stocks.

This ratio used to measure profitability in this research is the ratio that connected to the producer of profit that influenced by investment in certain assets level (Return On Asset / ROA). Return of Investment (ROI) shows company's ability to gain profit from assets used, by using this ratio we can see the efficiency company in using its assets for company's operating activity and also the impactiveness of the management in using the assets gets from profit.

\section{E. Framework}

The aim of this research is to determine how working capital ratio influence Return On Investment (ROI) in a company. ROI is one of the profitability ratio used as a measurement of working capital control. The increasing profit cannot give enough picture to show the impactiveness of the use of working capital, therefore a company tries to gain maximum ROI than maximum profit. Meanwhile, management's decision to looking at the operating assets on the statement of cash flow is also needed.

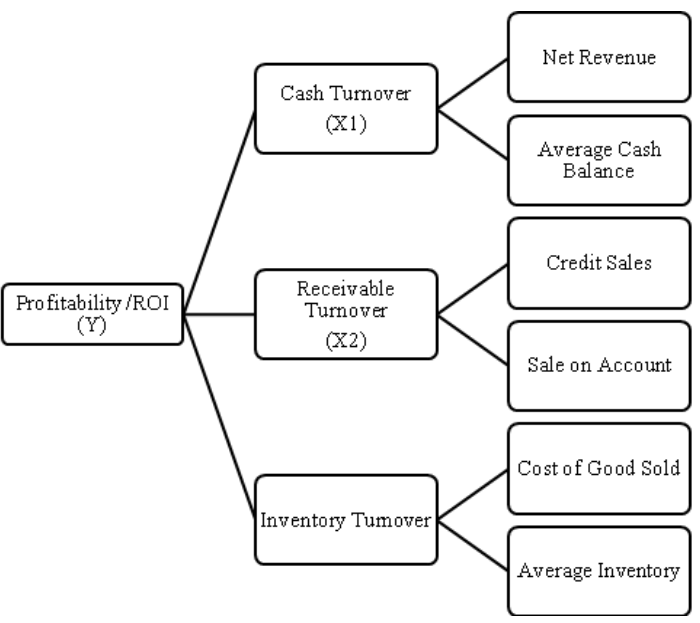

Picture 1. Research Framework

Muhammad Nur Rizqi: Analysis of Working Capital Turnover Impact Toward Profitability and Accounting Implication at PT. Multi Strada Arah Sarana Tbk. 


\section{E. Hypothesis}

Based on the framework above, the hypotheses in this research are:

$\mathrm{H}_{1}$ : Cash Turnover has positive impact toward Return on Investment at PT. Multistrada Arah Sarana. Tbk

$\mathrm{H}_{2}$ : Receivable Turnover has positive impact toward Return on Investment at PT. Multistrada Arah Sarana. Tbk

$\mathrm{H}_{3}$ : Inventory Turnover has positive impact toward Return on Investment at PT. Multistrada Arah Saraba. Tbk

$\mathrm{H}_{4}$ : Cash turnover, receivable turnover, and inventory turnover has positive impact toward Return on Investment at PT. Multistrada Arah Sarana. Tbk

\section{RESEARCH METHOD}

This research uses descriptive method. Some of the terms relates to this research are:

A. Independent variables $(X)$ are variables that influence dependent variables either positively or negatively. They are also free independent. The independent variables in this research are working capital that divided into cash turnover, receivable turnover and inventory turnover.

1. Cash turnover $\left(\mathrm{X}_{1}\right)$

2. Receivable turnover $\left(\mathrm{X}_{2}\right)$

3. Inventory turnover $\left(X_{3}\right)$

B. Dependent variables $(\mathrm{Y})$ is a variable that influenced by independent variables. This variable cannot stand alone. The dependent variable in this research is profitability.

C. Variable measurement

1. Independent variables $(X)$ which consist of cash turnover $\left(X_{1}\right)$, receivable turnover $\left(X_{2}\right)$, and inventory turnover $\left(X_{3}\right)$ are measured using ratio scale in a year.

2. Dependent variable that is profitability measured using Return on in percent (\%).

D. Collecting Data

The data collected is financial statement at PT. Multistrada Arah Sarana Tbk 2010-2016 periods.

E. Analysis technique and hypotheses test

1. Data analyzed using quantitative and statistic test $y$ analyzing multi linear regression, correlation analysis, determination coefficient, T-test and F-test (Anova). The analyses used to determine whether the independent variables has connection with the dependent variable, measure the significance and conclude the hypotheses.

2. Statistic tests:

a. Multi linear regression analysis to count the influence of independent variables working capital towards dependent variable $-\mathrm{ROI}$.

$$
\begin{aligned}
& Y=a+b_{1} X_{1}+b_{2} X_{2}+b_{3} X_{3}+e \\
& Y \quad=\text { Return on Invesment / ROI (Profitability) }
\end{aligned}
$$




$$
\begin{array}{ll}
\mathrm{a} & =\text { Constanta, the value of } \mathrm{Y} \text { if } \mathrm{X}=0 \\
\mathrm{~b}_{1}-\mathrm{b}_{3}= & \begin{array}{l}
\text { regression coefficient direction, that show the changing of the } \\
\text { number of } \mathrm{Y}, \text { if } \mathrm{X} \text { change }
\end{array} \\
\mathrm{X}_{1} & =\text { Cash turnover } \\
\mathrm{X}_{2} & =\text { Receivable turnover } \\
\mathrm{X}_{3} & =\text { Inventory turnover } \\
\mathrm{e} & =\text { error standard }
\end{array}
$$

b. Correlation analysis show the direction and the strength of the correlation between two variables.

$R y . x_{1} x_{2} x_{3}=\frac{r^{2} y x_{1}}{1}+\frac{r^{2} y x^{2}+r^{2} y x_{3}-2 r y x_{1} r y x_{2} r y x_{3}}{1-r^{2} x_{1} x_{2} x_{3}} \underline{x}_{2} \underline{x}_{2} \underline{x}_{3}$

$$
\begin{array}{ll}
\operatorname{Ry} . x_{1} x_{2} x_{3} & =\text { correlation between variables } X_{1}, X_{2}, X_{3} \\
\operatorname{ryx}_{1} & =\text { product moment correlation between } X_{1} \text { and } Y \\
\operatorname{ryx}_{2} & =\text { product moment correlation between } X_{2} \text { and } Y \\
\operatorname{ryx}_{3} & =\text { product moment correlation between } X_{3} \text { and } Y \\
\operatorname{rx}_{1} x_{2} x_{3} & =\text { product moment correlation between } X_{1} \text { and } X_{2} \text { and } X_{3}
\end{array}
$$

To measure the strength of the correlation between the two variables can be seen in some categoriries below:

\section{Table 1}

Coefficient correlation categories

\begin{tabular}{|l|l|}
\hline Coefficient Interval & Interpretation \\
\hline $0,00-0,199$ & Very low \\
\hline $0,20-0,399$ & Low \\
\hline $0,40-0,599$ & Average \\
\hline $0,60-0,799$ & Strong \\
\hline $0,80-1,000$ & Very strong \\
\hline
\end{tabular}

Source: Sugiyono, 2006:183

c. Determination coefficient, to measure the influence of dependent variable.

$$
\mathrm{KD}=\mathrm{r}^{2} \times 100 \%
$$

$\mathrm{KD}=$ determination correlation

$r=$ value of coefficient correlation 
Table 2

Interpretation Determination Coefficient

\begin{tabular}{|l|l|}
\hline Coefficient Interval & Interpretation \\
\hline $0 \%-20 \%$ & Very low \\
\hline $21 \%-40 \%$ & Low \\
\hline $41 \%-60 \%$ & Average \\
\hline $61 \%-80 \%$ & High \\
\hline $81 \%-100 \%$ & Very high \\
\hline
\end{tabular}

d. T-test

To determine the significance impact of the independent variable cash turnover $\left(X_{1}\right)$, receivable turnover $\left(X_{2}\right)$, and inventory turnover $\left(X_{3}\right)$ measured from the profitability $(\mathrm{Y})$ that measured from ROI at PT. Multistrada Arah Sarana. Tbk. The hypotheses formula are:

1) Cash turnover variable has impacts toward profitability (ROI)

$\mathrm{H}_{\mathrm{o}}$ : cash turnover has no significant impact toward profitability (ROI).

$\mathrm{H}_{\mathrm{a}}$ : cash turnover has significant impact toward profitability (ROI).

2) Receivable turnover variable has significant impact toward profitability (ROI)

$\mathrm{H}_{\mathrm{o}}$ : receivable turnover has no significant impact toward profitability (ROI)

$\mathrm{H}_{\mathrm{a}}$ : receivable turnover has significant impact toward profitability (ROI)

3) Inventory turnover has significant impact toward profitability (ROI)

$\mathrm{H}_{\mathrm{O}}$ : Inventory turnover has no significant impact toward profitability (ROI)

$\mathrm{H}_{\mathrm{a}}$ : Inventory turnover has significant impact toward profitability (ROI)

Criteria uses are:

a) $H_{o}$ is acceptable if $t_{\text {result }}<t_{\text {table }}, H_{a}$ is rejected if $t_{\text {count }}>t_{\text {table }}$

b) Based on profitability value (significant), can be concluded:

If profitability $>0,05$ means $H_{0}$ is acceptable, if profitability $<0,05$ means $\mathrm{H}_{\mathrm{a}}$ is rejected.

4) F-test (Annova). To interpret the significant coefficient independent variables of working capital (cash turnover, receivable turnover, and inventory turnover) toward dependent variable, profitability measured by ROI.

a) $H_{0}$ : there is no significant impact between cash turnover, receivable turnover and inventory turnover at the same time toward ROI.

b) $\mathrm{H}_{\mathrm{a}}$ : there is a significant impact between cash turnover, receivable turnover and inventory turnover at the same time toward ROI.

5) Significance level determination

The level if significance chosen in this research is $\alpha=5 \%$. This is the general significance level used and fit in the research represent the correlation between variables studied. Can be concluded if $\mathrm{H}_{0}$ is accepted, ROI wrongly reject the hypotheses $\alpha=0$.

3. The counting implication will be analyzed descriptively. 


\section{RESULT AND DISCUSSION}

A. PT. Multistrada Arah Sarana Tbk (MASA), were established in 1988 in the name of PT. Oroban perkasa becomes one of the most famous tire producer in Indonesia with the high quality motorcycles and cars tires which are ready to serve dynamic domestic and also potential export market. This company has a large factory that use modern technology base located in East Cikarang - Bekasi, West Java. In the previous, this factory were established with technical assistant from Pirelli Italy, but then continued by continental Gmbh Germany. The turning point of this company happened when this factory acquired by PVP XVII Ltd and PT. Indokemika Jayatama in 2004, followed by IPO that succeed in 2005.

B. Statistic Test - Multi Linear Regression Analysis

To determine the correlation between the three sub variables (cash turnover, receivable turnover, and inventory turnover) toward Return On Investment in the company. Below are the data used in this study.

Table 3 Return On Investment (in 000 US Dollar)

\begin{tabular}{|c|r|r|r|}
\hline Year & $\begin{array}{c}\text { Net Income After } \\
\text { Tax }\end{array}$ & Total Assets & ROI (Y) \\
\hline 2010 & $14,789.00$ & $360,935.00$ & $4.10 \%$ \\
\hline 2011 & $6,943.00$ & $538,091.00$ & $1.29 \%$ \\
\hline 2012 & 320.00 & $624,486.00$ & $0.05 \%$ \\
\hline 2013 & $3,601.00$ & $629,066.00$ & $0.57 \%$ \\
\hline 2014 & 473.00 & $625,204.00$ & $0.08 \%$ \\
\hline 2015 & $(26,859.00)$ & $598,429.00$ & $-4.49 \%$ \\
\hline 2016 & $(6,702.00)$ & $609,745.00$ & $-1.10 \%$ \\
\hline
\end{tabular}

Source : PT. Multistrada Arah Sarana, processed.

Table 4 Capital Working Turnover

\begin{tabular}{|c|c|c|c|}
\hline Year & $\begin{array}{c}\text { Cash } \\
\text { turnover }\end{array}$ & $\begin{array}{c}\text { Receivable } \\
\text { turnover }\end{array}$ & $\begin{array}{c}\text { Inventory } \\
\text { turnover }\end{array}$ \\
\hline $\mathrm{n}$ & $\mathrm{X}_{\mathbf{1}}$ & $\mathrm{X}_{\mathbf{2}}$ & $\mathrm{X}_{\mathbf{3}}$ \\
\hline 2010 & 44.17 & 18 & 4 \\
\hline 2011 & 65.99 & 16 & 4 \\
\hline 2012 & 6.91 & 13 & 3 \\
\hline 2013 & 9.33 & 11 & 4 \\
\hline 2014 & 6.60 & 9 & 3 \\
\hline 2015 & 6.18 & 8 & 3 \\
\hline 2016 & 16.40 & 7 & 3 \\
\hline
\end{tabular}

Source : PT. Multistrada Arah Sarana

1. Determination coefficient test $\left(R^{2}\right)$

To determine the strength correlation between the two variables and the standard used, the correlation coefficient needed. Below are the result: 
Table 5 Determination coefficient test $\left(R^{2}\right)$

Model Summary

\begin{tabular}{|l|l|l|l|l|}
\hline Model & $R$ & R Square & $\begin{array}{l}\text { Adjusted R } \\
\text { Square }\end{array}$ & $\begin{array}{l}\text { Std. Error of } \\
\text { the Estimate }\end{array}$ \\
\hline 1 &, $833^{\mathrm{a}}$ &, 693 &, 386 & 1,17543 \\
\hline
\end{tabular}

a. Predictors: (Constant), Cash Turnover, Receivable Turnover, Inventory Turnover

Based on the data above, the Adjusted $R$ Square is 0,386 that means the independent variable of cash turnover $\left(X_{1}\right)$, receivable turnover $\left(X_{2}\right)$ and inventory turnover $\left(X_{3}\right)$ can define the low impact of $38,6 \%$ profitability variable / ROI $(Y)$, the rest of $61,4 \%$ define by another variables that are not included in regression models.

2. F-test or Annova

F-test conducted to test if the independent variable $(X)$ cash turnover, receivable turnover and inventory turnover at the same time has any impact toward profitability / ROI (Y).

$H_{0}$ : Variable cash turnover $\left(X_{1}\right)$, receivable turnover $\left(X_{2}\right)$ and inventory turnover $\left(X_{3}\right)$ at the same time has no significant impact toward profitability (ROI).

$H_{a}$ : Variable cash turnover $\left(X_{1}\right)$, receivable turnover $\left(X_{2}\right)$ and inventory turnover $\left(X_{3}\right)$ at the same time has significant impact toward profitability (ROI).

The result of the study by using SPSS 16.0 program can be shown output $f$ value below:

Table 6

F-test Result

ANOVA $^{\mathrm{a}}$

\begin{tabular}{|c|c|c|c|c|c|c|}
\hline \multicolumn{2}{|c|}{ Model } & $\begin{array}{c}\text { Sum of } \\
\text { Squares }\end{array}$ & $\mathrm{Df}$ & Mean Square & $\mathrm{F}$ & Sig. \\
\hline \multirow{3}{*}{1} & Regression & 9,365 & 3 & 3,122 & \multirow[t]{3}{*}{2,259} & \multirow[t]{3}{*}{, $260^{b}$} \\
\hline & Residual & 4,145 & 3 & 1,382 & & \\
\hline & Total & 13,510 & 6 & & & \\
\hline
\end{tabular}

a. Dependent Variable: ROI

b. Predictors: (Constant), Cash turnover, receivable turnover, inventory turnover

Annova table above identified that the significance level $(0,260)>0,06$. It means that independent variable cash turnover, receivable turnover and inventory turnover at the same time has no significant impact toward profitability (ROI).

3. Multi Linear Regression Analysis

To determine the correlation between the three sub variables (cash turnover, receivable turnover and inventory turnover) toward return on investment in the company.

Muhammad Nur Rizqi: Analysis of Working Capital Turnover Impact Toward Profitability and Accounting Implication at PT. Multi Strada Arah Sarana Tbk. 
Table 7

Multi Linear Regression Result

\begin{tabular}{|c|c|c|c|c|c|}
\hline \multirow[t]{2}{*}{ Model } & \multicolumn{2}{|c|}{$\begin{array}{l}\text { Unstandardized } \\
\text { Coefficients }\end{array}$} & \multirow{2}{*}{\begin{tabular}{|l}
$\begin{array}{l}\text { Standardize } \\
\text { d }\end{array}$ \\
Coefficients \\
Beta \\
\end{tabular}} & \multirow[t]{2}{*}{$\mathrm{T}$} & \multirow[t]{2}{*}{ Sig. } \\
\hline & $B$ & Std. Error & & & \\
\hline (Constant) & $-3,899$ & 3,918 & &,- 995 & ,393 \\
\hline Cash turnover &,- 001 &, 033 &,- 009 &,- 017 & ,987 \\
\hline Receivable turnover &, 247 & ,198 & ,684 & $\begin{array}{l}1,24 \\
6\end{array}$ & ,301 \\
\hline Inventory turnover &, 550 & 1,407 & ,196 & ,391 & ,722 \\
\hline
\end{tabular}

a. Dependent Variable: ROI

From the table above, can be concluded the multi linear regression equation is:

$Y=-3,899-0,001 X_{1}+0,247 X_{2}+0,550 X_{3}$

From the equation above we can see that:

a. Cash turnover variable has no significant impact toward profitability (ROI). It can be seen on the significance of $0,987>0,05$ and $t_{\text {result }}(-0,17)<t_{\text {table }}$ $(3,182)$. It shows that the partially increase cash turnover has no significant impact toward profitability (ROI).

b. Receivable turnover has no significant impact toward profitability (ROI). It can be seen on the significance of $0,301>0,05$ and $t_{\text {result }}(1,246)<t_{\text {table }}(3,182)$. It shows that the partially increase receivable turnover has no significant impact toward profitability (ROI).

C. Inventory turnover variable has no significant impact toward profitability (ROI). It is because the significance of $0,722>0,05$. $t_{\text {result }}(0,391)<t_{\text {table }}$ which means that the partially increase inventory turnover has no significant impact toward profitability (ROI).

C. Considering the statistic test and the discussion above, we can see that the working capital turnover (cash turnover, receivable turnover, and inventory turnover) has no significant impact toward profitability. While on the cash flow especially on the operating activity, mentioned that net cash obtained by the company in 2010-1016 is positive, even the value is fluctuated.

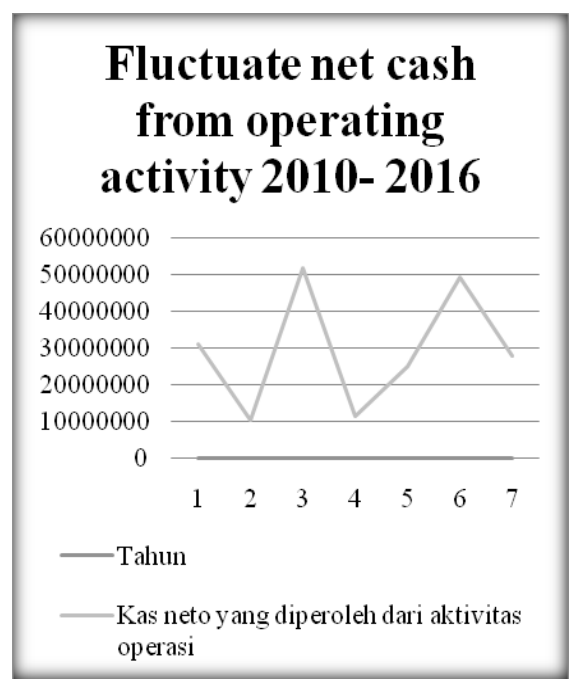

Picture 2 Fluctuate Net Cash

Muhammad Nur Rizqi: Analysis of Working Capital Turnover Impact Toward Profitability and Accounting Implication at PT. Multi Strada Arah Sarana Tbk. 
During 2012 cash flow from operating activity increase significantly from USD11 Million to USD52 Million from the previous years. This is mainly because of the increasing of cash accepted by the customers impacted by good controlled of withdrawal of account receivable. Individual asset in the end of 2014 is USD167,6 million, it increase as $2,4 \%$ from the previous years of USD 62,3 million. The increase caused by the increase of cash account in $24 \%$.

\section{CONCLUSION AND SUGGESTIONS}

A. Conclusion

Considering the result of the study at PT. Multistrada Arah Sarana, Tbk about the processing of cash turnover $\left(\mathrm{X}_{1}\right)$, receivable turnover $\left(\mathrm{X}_{2}\right)$ and inventory turnover

$\left(X_{3}\right)$ variables toward dependent variable of profitability $(Y)$ can be concluded that:

1. Cash turnover $\left(\mathrm{X}_{1}\right)$ has no significant impact toward profitability / $\mathrm{ROI}(\mathrm{Y})$.

2. Receivable turnover $\left(\mathrm{X}_{2}\right)$ has no significant impact toward profitability / ROI (Y) because the turnover from 2010-1016 tend to decrease.

3. Inventory turnover $\left(\mathrm{X}_{3}\right)$ has no significant impact toward profitability / ROI ( $\mathrm{Y}$ ) because the turnover looks stagnant.

4. The three sub variables has no significant impact toward profitability (ROI).

5. Accounting implication from the result of the study is that ROI, either positive or negative show the unidirectional / not linear to cash from operating result.

B. Suggestion

Based on the conclusion above, the researcher can suggest that:

1. The company should optimize the use of cash for operating activity so the turnover can be faster. Moreover the decreasing of receivable turnover, management should pay attention to the procedures of giving receivable account by looking at the character, capacity, and condition of the customer, and also make the optimal withdrawal schedule. For the inventory turnover which is stagnant, company should use Just In Time management as well as optimizing the cash. Just In Time can make the turnover faster to increase the ROI.

2. Although there is no linear between the research result that says there is no significant of all sub working capital towards profitability / ROI with cash income from operating activity, management should pay attention the overall cash flow statement, because it says the positive yet fluctuate all years.

\section{REFERENCES}

Bambang Riyanto, Dasar-Dasar Pembelanjaan Perusahaan, Fourth Edition, Eighth Printed, Yogyakarta ; BPFE, 2008.

Baridwan, Zaki, Intermediate Accounting, Seventh Edition, Yogyakarta : BPFE. 2008

Djarwanto, PS, Pokok-pokok Analisa Laporan Keuangan, First Edition, Eighth Printed Yogyakarta; BPFE 2001

Mamduh M Hanafi, dan Abdul Halim, Analisis Laporan keuangan, Third Edition, First Printed, Yogyakarta. 2007

Raharjaputra, Hendra. Manajemen Keuangan dan Akuntansi. Jakarta: Salemba. 2009

Mardiana Astria, (2014) Analisis Pengaruh Perputaran Kas, Piutang,dan Persediaan terhadap Profitabilitas pada PT. Swanish Boga Industria. Bogor. STIE Binaniaga

Muhammad Nur Rizqi: Analysis of Working Capital Turnover Impact Toward Profitability and Accounting Implication at PT. Multi Strada Arah Sarana Tbk. 
The Accounting Journal of BINANIAGA Vol. 02, No. 02, December 2017

PISSN: $2527-4309$

EISSN: $2580-1481$

R. Agus Sartono, Manajemen Keuangan Teori dan Aplikasi, Forth Edition, Seventh Printed. Yogyakarta; BPFE 2001

Sugiyono,Metode Penelitian Bisnis, Bandung : CV. Alfabeta, 2006

S. Munawir, Analisa Laporan Keuangan Ed Keempat, Cetakan Keempat Belas, Yogyakarta. ; Liberty 2004

Skousen K, Fred., James D. Stice., Earl K. Stice, Intermediate Accounting (Terjemah Ali Akbar), Edisi Enam belas, Buku satu, Jakarta, Salemba Empat. 2007 